International Journal of Medical Sciences

ISSN 1449-1907 www.medsci.org 2007 4(3):146-152

Research Paper

(C) Ivyspring International Publisher. All rights reserved

\title{
A Novel Variable Number of Tandem Repeat of the Natriuretic Peptide Precursor B gene's 5'-Flanking Region is Associated with Essential Hyper- tension among Japanese Females
}

\author{
Kotoko Kosuge ${ }^{1}$, Masayoshi Soma1,3, Tomohiro Nakayama², Noriko Aoi ${ }^{2}$, Mikano Sato ${ }^{2}$, Yoichi Izumi', \\ Koichi Matsumoto1
}

1. Division of Nephrology and Endocrinology, Department of Medicine, Nihon University School of Medicine, Tokyo, Japan

2. Division of Molecular Diagnostics, Advanced Medical Research Center, Nihon University School of Medicine, Tokyo, Ja-

pan

3. Division of General Medicine, Department of Medicine, Nihon University School of Medicine, Tokyo, Japan

Correspondence to: Tomohiro Nakayama M.D., Division of Molecular Diagnostics, Advanced Medical Research Center, Nihon University School of Medicine, 30-1 Ooyaguchi-kamimachi, Itabashi-ku, Tokyo 173-8610, Japan. Tel: +81 3-3972-8111 (Ext. 8205); Fax: +81 3-5375-8076; E-mail: tnakayam@med.nihon-u.ac.jp

Received: 2006.12.04; Accepted: 2007.05.15; Published: 2007.05.16

Background: Brain natriuretic peptide (BNP) acts primarily as a cardiac hormone; it is produced by the ventricle and has both vasodilatory and natriuretic actions. Therefore, the BNP gene is thought to be a candidate gene for essential hypertension (EH). The present study identified variants in the $5^{\prime}$-flanking region of natriuretic peptide precursor $\mathrm{B}(N P P B)$ gene and assessed the relationship between gene variants and $\mathrm{EH}$.

Methods: The polymerase chain reaction-single strand conformation polymorphism method and nucleotide sequencing were used to identify variants.

Results: A novel variable number of tandem repeat (VNTR) polymorphism in the 5 '-flanking region (-1241 nucleotides from the major transcriptional initiation site) was discovered. This VNTR polymorphism is a tandem repeat of the 4-nucleotide sequence TTTC. There were 8 alleles, ranging from 9-repeat to 19-repeat. An association study was done involving $317 \mathrm{EH}$ patients and 262 age-matched normotensive (NT) subjects. The 11-repeat allele was the most frequent $(88.2 \%)$; the 16-repeat allele was the second most frequent $(10.5 \%)$ in the NT group. The observed and expected genotypes were in agreement with the predicted Hardy-Weinberg equilibrium values $(\mathrm{P}=0.972)$. Among females, the overall distribution of genotypes was significantly different between the $\mathrm{EH}$ and NT groups $(p=0.039)$. The frequency of the 16-repeat allele was significantly lower in the female EH group $(6.5 \%)$ than in the female NT group $(12.2 \%, \mathrm{p}=0.046)$.

Conclusions: The 16-repeat allele of the VNTR in the $5^{\prime}$-flanking region of NPPB appears to be a useful genetic marker of EH in females.

Key words: Brain natriuretic peptide, essential hypertension, variable number of tandem repeat, association study

\section{Introduction}

Natriuretic peptides constitute a family of three structurally related molecules: atrial natriuretic peptide (ANP) [1], brain natriuretic peptide (BNP) [2], and C-type natriuretic peptide (CNP) [3]. ANP and BNP act mainly as cardiac hormones and are produced primarily by the atria and ventricles, respectively, whereas C-type natriuretic peptide is expressed mainly in the brain $[4,5]$.

BNP, which was originally isolated from the porcine brain [6], shows an amino acid sequence homology to ANP. BNP has central and peripheral actions that are similar to those of ANP. The heart has the highest concentrations of BNP, and BNP acts as a cardiac hormone. Intravenous injection of BNP causes a significant decrease in blood pressure [7]. Transgenic mice that overexpress BNP have a measurable reduc- tion in blood pressure [8]. Mukoyama et al. showed that plasma BNP levels are higher in individuals with essential hypertension (EH) than in normotensive (NT) individuals [7]. These findings suggest that the BNP gene is a candidate gene for $\mathrm{EH}$. $\mathrm{EH}$ is thought to be a multifactorial disorder; several studies have shown that an association analysis with genetic variants can be used to identify susceptibility genes for $\mathrm{EH}$ [9].

The aim of the present study was to identify mutations or polymorphisms in the $5^{\prime}$-flanking region of the NPPB gene and to assess the relationship between variants of the gene and $\mathrm{EH}$.

\section{Subjects and Methods}

\section{Subjects}

The EH group consisted of 317 patients (mean age, $49.7 \pm 7.8$ years) with $\mathrm{EH}$ diagnosed based on sitting systolic blood pressure (SBP) greater than 160 
$\mathrm{mmHg}$ and/or diastolic blood pressure (DBP) greater than $100 \mathrm{mmHg}$ measured on three separate occasions within 2 months after the initial BP measurement (Table 1). These patients were not being treated with antihypertensive drugs. All $\mathrm{EH}$ subjects had a positive family history of hypertension; patients diagnosed with secondary hypertension were excluded from the study. We also enrolled 262 healthy, normotensive (NT) subjects (mean age, $51.2 \pm 10.8$ years). None of the NT subjects had a family history of hypertension; all had an SBP less than $130 \mathrm{mmHg}$ and a DBP less than $85 \mathrm{mmHg}$. A family history of hypertension was defined as having grandparents, uncles, aunts, parents, or siblings who had been diagnosed with hypertension. Written informed consent was obtained from each subject based on a protocol approved by the Ethics Committee of the Nihon University School of Medicine and the Clinical Studies Committee of Nihon University Hospital [10].

Table 1. Characteristics of study participants

\begin{tabular}{|c|c|c|c|c|c|c|c|c|c|}
\hline & \multicolumn{3}{|c|}{ Total } & \multicolumn{3}{|c|}{ Males } & \multicolumn{2}{|c|}{ Females } & \multirow[b]{2}{*}{$\mathrm{p}$ Value } \\
\hline & NT & $\mathrm{EH}$ & $\mathrm{p}$ Value & NT & $\mathrm{EH}$ & $\mathrm{p}$ Value & NT & $\mathrm{EH}$ & \\
\hline No. of subjects & 262 & 317 & & 184 & 193 & & 78 & 124 & \\
\hline Age (years) & $51.2 \pm 10.8$ & $49.7 \pm 7.8$ & 0.052 & $50.1 \pm 9.4$ & $48.5 \pm 8.4$ & 0.072 & $53.6 \pm 13.2$ & $51.5 \pm 6.5$ & 0.135 \\
\hline BMI $\left(\mathrm{kg} / \mathrm{m}^{2}\right)$ & $22.6 \pm 4.0$ & $24.6 \pm 4.4$ & $<0.001$ & $22.9 \pm 3.4$ & $24.7 \pm 4.7$ & $<0.001$ & $21.6 \pm 5.1$ & $24.3 \pm 3.9$ & $<0.001$ \\
\hline $\mathrm{SBP}(\mathrm{mmHg})$ & $113 \pm 11$ & $173 \pm 20$ & $<0.001$ & $114 \pm 10$ & $171 \pm 19$ & $<0.001$ & $113 \pm 11$ & $175 \pm 23$ & $<0.001$ \\
\hline $\mathrm{DBP}(\mathrm{mmHg})$ & $70 \pm 8$ & $107 \pm 13$ & $<0.001$ & $70 \pm 8$ & $108 \pm 13$ & $<0.001$ & $69 \pm 9$ & $105 \pm 14$ & $<0.001$ \\
\hline Creatinine (mg/dl) & $0.85 \pm 0.22$ & $0.85 \pm 0.26$ & 0.928 & $0.92 \pm 0.20$ & $0.94 \pm 0.26$ & 0.302 & $0.69 \pm 0.18$ & $0.69 \pm 0.18$ & 0.766 \\
\hline Total cholesterol (mg/dl) & $197 \pm 44$ & $212 \pm 43$ & $<0.001$ & $193 \pm 42$ & $209 \pm 46$ & 0.001 & $208 \pm 46$ & $217 \pm 38$ & 0.141 \\
\hline HDL cholesterol (mg/dl) & $57 \pm 17$ & $56 \pm 17$ & 0.256 & $56 \pm 16$ & $52 \pm 15$ & 0.022 & $61 \pm 19$ & $62 \pm 17$ & 0.972 \\
\hline Uric acid (mg/dl) & $5.8 \pm 4.4$ & $6.0 \pm 7.4$ & 0.610 & $5.8 \pm 1.3$ & $6.1 \pm 1.4$ & 0.018 & $5.6 \pm 8.0$ & $5.9 \pm 11.8$ & 0.894 \\
\hline
\end{tabular}

BMI, body mass index; SBP, systolic blood pressure; DBP, diastolic blood pressure; HDL, high-density lipoprotein; NT, normotensives; EH, essential hypertension

\section{Biochemical analysis}

Plasma total cholesterol concentrations, as well as serum creatinine and uric acid concentrations, were measured using standard methods in the Clinical Laboratory Department of Nihon University Hospital [11]. Plasma BNP levels were measured in NT subjects and EH patients. A total of 76 subjects (43 in the NT group and 33 in the EH group) who did or did not have the 16 repeat allele were selected randomly. Plasma BNP levels were measured using a highly sensitive immunoradiometric assay (Shiono RIA BNP assay kit, Shionogi Co., Ltd., Tokyo, Japan) as described previously [12].

\section{Polymerase chain reaction - single strand confor- mation polymorphism (PCR-SSCP)}

Genomic DNA was extracted from peripheral blood leukocytes using a standard method [13]. To screen for mutations, two oligonucleotide primers (sense, 5'- AAGGAGGCACTGGGAGAGGGGAAAT $-3^{\prime}$ (bases -1323 to -1299 from the major transcriptional initiation site) and antisense, 5'-AATTAGCTGGGCATGGTGGCAGGCG-3' (bases -1075 to -1051$)$ ) that recognize part of the $5^{\prime}$-flanking region of the NPPB gene were designed, since this region has been reported to be a major promoter region (Fig. 1A) [14]. PCR-SSCP was done (GenePhor System; Amersham Biosciences Corp, Piscataway, NJ, USA) [15]. PCR was performed using a GeneAmp PCR system 9700 (Applied Biosystems, Branchburg, NJ, USA) with the following amplification conditions: initial denaturation at $96^{\circ} \mathrm{C}$ for $3 \mathrm{~min}$ followed by 35 cycles of $98.5^{\circ} \mathrm{C}$ for $25 \mathrm{~s}, 65^{\circ} \mathrm{C}$ for $30 \mathrm{~s}, 68^{\circ} \mathrm{C}$ for $30 \mathrm{~s}$, and a final extension of $68^{\circ} \mathrm{C}$ for $10 \mathrm{~min}$. PCR products were separated by electrophoresis on $10 \%$ precast polyacrylamide gels (Amersham Biosciences Corp) at $5^{\circ} \mathrm{C}$ for $80 \mathrm{~min}$ and then subjected to silver staining (Dai-ichi Kagaku, Tokyo, Japan). The electrophoresis parameters were set according to the manufacturer's protocol.

\section{Sequencing analysis}

Two oligonucleotides (sense, 5'-AAGGAGGCACTGGGAGAGGGGAAAT-3' (bases -1323 to -1299) and antisense, 5' CCCCACCAAGCCAACACAGGATGGA -3' (bases -919 to-895) were used to amplify a 429-bp product from genomic DNA (Fig. 1A). The PCR products were purified using a Microcon 100 column (U.S. Amicon Inc. Beverly, MA,USA). The resulting products were ligated to $\mathrm{pCR} 2.1^{\mathrm{TM}}$ vectors and cloned (TA Cloning Kit, Invitrogen, San Diego, CA, USA). The ligation of the products was confirmed by direct DNA sequencing (ABI PRISM 310 Genetic Analyzer) [16].

\section{Genotyping}

Genotyping was done using fragment analysis, and the sequencing primers were used. PCR amplification consisted of an initial denaturation at $94^{\circ} \mathrm{C}$ for 3 min, followed by 35 cycles of $98.5^{\circ} \mathrm{C}$ for $25 \mathrm{sec}, 63^{\circ} \mathrm{C}$ for $30 \mathrm{~s}, 72^{\circ} \mathrm{C}$ for $1 \mathrm{~min}$, and a final extension of $72^{\circ} \mathrm{C}$ for 10 $\mathrm{min}$. Then, the PCR products were analyzed using an automatic electrophoresis system (Agilent 2100 bioanalyzer system ${ }^{\mathrm{TM}}$; Agilent Technologies, Waldbronn, Germany). 


\section{Statistical analysis}

Data are presented as the mean \pm SD. The Hardy-Weinberg equilibrium was assessed by doing chi-square $\left(\chi^{2}\right)$ analysis. Differences in the clinical data between the $\mathrm{EH}$ and NT groups were assessed by analysis of variance (ANOVA). The distributions of the genotypes or alleles between EH patients and NT subjects were tested using a two-sided Fisher's exact test. Multiple logistic regression analyses were done to assess the contribution of confounders (gender, BMI) [17]. A value of $P<0.05$ was considered statistically significant.

A

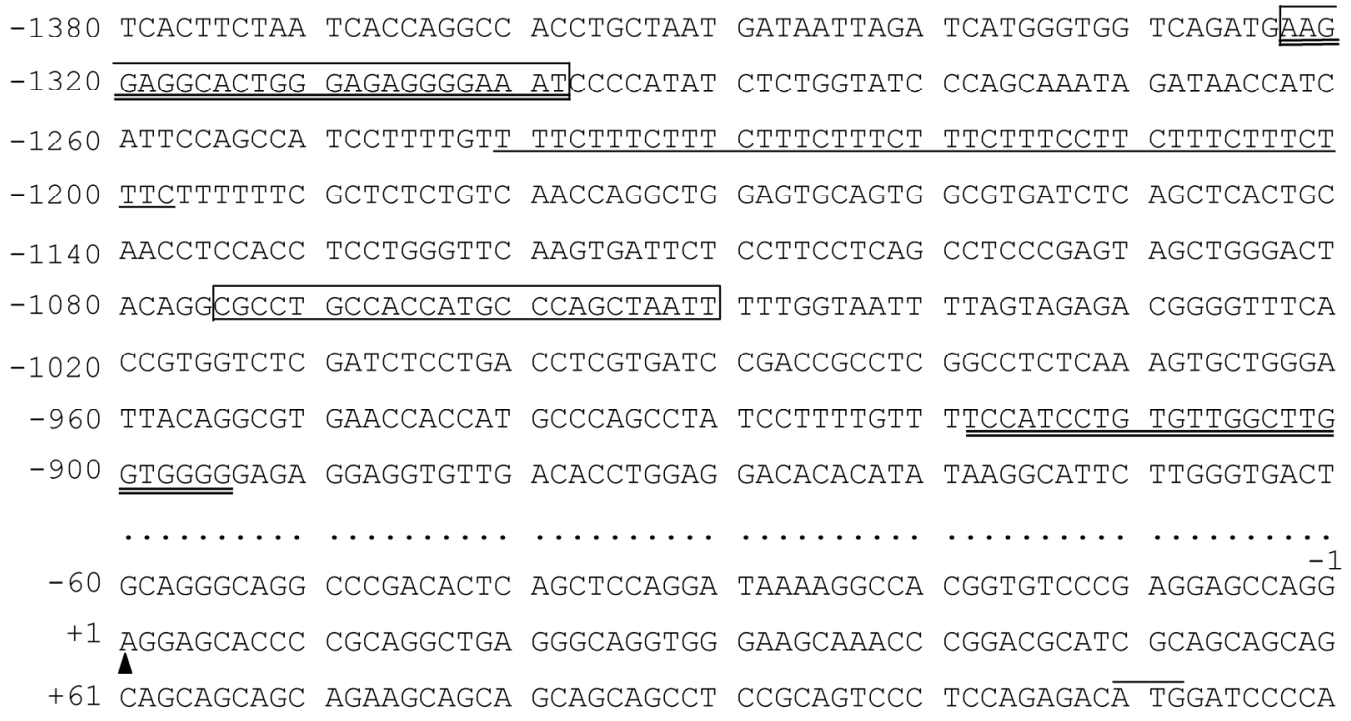

Figure 1 A: Nucleotide sequence of the 5'-flanking region of the human $N P P B$ gene. The nucleotide sequences are numbered (left) with respect to the major transcription start site (designated +1 ; closed triangle). Boxes, the primers (PCR-SSCP); double underlining, the primers (sequence and genotyping); overlining, ATG initiation codon; Underlining, the variable number of tandem repeat (VNTR) consists of the 4 nucleotides (TTTC). This figure shows the 11 repeat types. B: Nucleotide sequence of the 11 and 16 repeat allele.

\section{Results}

We discovered a novel variable number of tandem repeat (VNTR) polymorphism consisting of a 11-nucleotide repeat of 4 base pairs (bp) in the 5 '-flanking region (-1241 nucleotides from the major transcriptional initiation site) (GenBank accession number AB265677). This VNTR polymorphism is a tandem repeat of the 4-nucleotide sequence TTTC (Fig. 1A). There were 8 alleles of this VNTR polymorphism, ranging from 9-repeat to 19-repeat (Fig. 1B).

The association study showed that the 11-repeat allele was most frequent in the NT group $(88.2 \%)$. The 16-repeat allele was second most frequent in the NT group $(10.5 \%)$. Furthermore, in the NT group, the observed and expected genotypes were in good agreement with the predicted Hardy-Weinberg equilibrium values $(\mathrm{P}=0.972)$. Of note, the overall distribution of genotypes in females was significantly different between the EH and NT groups ( $p=0.039)$; the frequency of the 16-repeat allele was significantly lower in the
EH group $(6.5 \%)$ than in the NT group $(12.2 \%, p=0.046)$ (Table 2).

On multiple logistic regression analysis, a significant association between allele $16(\mathrm{p}=0.034)$ and female gender was noted, even after adjustment for confounding factors; the calculated odds ratio was 1.18 (95\% CI: 1.07-1.20).

The clinical data of each genotype were assessed. There were no significant differences in SBP and DBP levels, or in the pulse of subjects with or without the 16 repeat allele (Table 3 ).

The plasma BNP level was significantly higher in the $\mathrm{EH}$ group than in the NT group $(\mathrm{p}=0.0203)$. The plasma BNP level in each genotype with or without the 16 repeat allele was determined (Table 4); there were no significant differences among the groups. It was impossible to perform this analysis in EH females, as none of them had the 16 repeat allele.

All subjects were classified into 3 groups based on their BMI levels (lean, BMI $<18.5$; normal, $18.5<\mathrm{BMI}<25$; obese, BMI >25). There was no associa- 
Int. J. Med. Sci. 2007, 4

tion between the genotype and the BMI among the groups (Table 5).

Table 2. Genotype distribution in NT subjects and EH patients

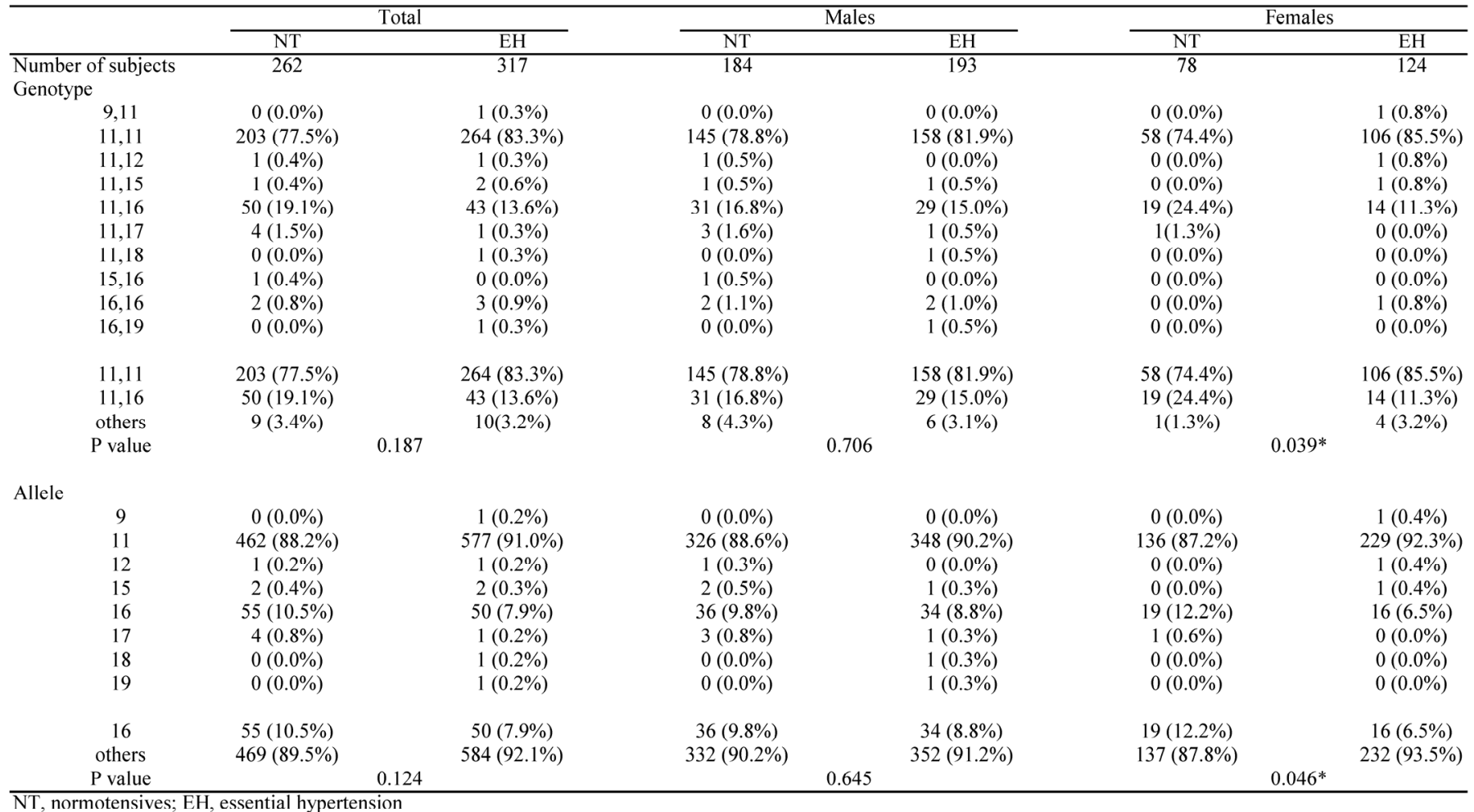

$*, p<0.05$.

Table 3. The association between genotype and phenotype

\begin{tabular}{|c|c|c|c|c|c|c|c|c|c|}
\hline \multirow[b]{2}{*}{ genotype } & \multicolumn{3}{|c|}{ Total } & \multicolumn{3}{|c|}{ Males } & \multicolumn{3}{|c|}{ Females } \\
\hline & vithout 16 repeat & with 16 repeat & $P$ value & without 16 repeat & with 16 repeat & $P$ value & without 16 repeat & with 16 repeat & $P$ value \\
\hline No. of subjects & 479 & 100 & & 311 & 66 & & 168 & 34 & \\
\hline SBP & $146.4 \pm 33.7$ & $143.1 \pm 35.4$ & 0.387 & $142.9 \pm 31.9$ & $143.1 \pm 35.0$ & 0.950 & $152.9 \pm 35.8$ & $143.1 \pm 36.8$ & 0.152 \\
\hline DBP & $90.5 \pm 21.5$ & $88.2 \pm 21.8$ & 0.324 & $89.7 \pm 21.9$ & $88.9 \pm 21.7$ & 0.783 & $92.0 \pm 20.9$ & $86.8 \pm 22.3$ & 0.189 \\
\hline Pulse & $76.5 \pm 14.2$ & $77.0 \pm 14.1$ & 0.775 & $76.1 \pm 14.5$ & $76.7 \pm 15.3$ & 0.785 & $77.1 \pm 13.7$ & $77.5 \pm 11.6$ & 0.889 \\
\hline
\end{tabular}

SBP; systolic blood pressure, DBP; diastolic blood pressure

Table 4. Plasma BNP levels for patients with or without 16 repeat

\begin{tabular}{|c|c|c|c|c|c|c|c|c|c|c|c|c|}
\hline & \multicolumn{4}{|c|}{ Total } & \multicolumn{4}{|c|}{ Male } & \multicolumn{4}{|c|}{ Female } \\
\hline & NT & & EH & & NT & & EH & & NT & & EH & \\
\hline & $\begin{array}{l}\text { No. of } \\
\text { subjects }\end{array}$ & $\overline{\mathrm{BNP}}(\mathrm{pg} / \mathrm{ml})$ & $\begin{array}{l}\text { No. of } \\
\text { subjects }\end{array}$ & $\mathrm{BNP}(\mathrm{pg} / \mathrm{ml})$ & $\begin{array}{c}\text { No. of } \\
\text { subjects }\end{array}$ & $\overline{\mathrm{BNP}}(\mathrm{pg} / \mathrm{ml})$ & $\begin{array}{l}\text { No. of } \\
\text { subjects }\end{array}$ & $\mathrm{BNP}(\mathrm{pg} / \mathrm{ml})$ & $\begin{array}{l}\text { No. of } \\
\text { subjects }\end{array}$ & $\mathrm{BNP}(\mathrm{pg} / \mathrm{ml})$ & $\begin{array}{c}\text { No. of } \\
\text { subjects }\end{array}$ & $\overline{\mathrm{BNP}(\mathrm{pg} / \mathrm{ml})}$ \\
\hline without 16 repeat & 33 & $5.3 \pm 5.3$ & 31 & $17.0 \pm 32.2$ & 26 & $4.4 \pm 5.0$ & 18 & $10.8 \pm 11.6$ & 7 & $8.4 \pm 5.1$ & 13 & $25.5 \pm 47.6$ \\
\hline with 16 repeat & 10 & $4.3 \pm 3.5$ & 2 & $8.2 \pm 2.6$ & 7 & $3.4 \pm 2.3$ & 2 & $8.2 \pm 2.6$ & 3 & $6.5 \pm 5.5$ & 0 & - \\
\hline $\mathrm{p}$ value & & 0.611 & & 0.703 & & 0.628 & & 0.748 & & 0.602 & & - \\
\hline
\end{tabular}

Table 5. Distribution of subjects by BMI

\begin{tabular}{|c|c|c|c|c|c|c|c|c|c|c|c|c|}
\hline & \multicolumn{4}{|c|}{ Total } & \multicolumn{4}{|c|}{ Males } & \multicolumn{4}{|c|}{ Females } \\
\hline & Lean & Normal & Obese & $\mathrm{P}$ value & Lean & Normal & Obese & $P$ value & Lean & Normal & Obese & $P$ value \\
\hline without 16 repeat & 22 & 285 & 134 & & 13 & 186 & 88 & & 9 & 99 & 46 & \\
\hline with 16 repeat & 1 & 58 & 33 & & 1 & 35 & 24 & & 0 & 23 & 9 & \\
\hline $\mathrm{p}$ value & & & & 0.179 & & & & 0.262 & & & & 0.345 \\
\hline
\end{tabular}

Lean;18.5>BMI, Normal; $18.5<\mathrm{BMI}<25$, Obese; $25<\mathrm{BMI}$ 


\section{Discussion}

Ogawa et al. reported that the 5'-flanking region of the 1.9 kilo-base pairs in the NPPB gene has a high transcriptional activity. Using the deletion mutant model, the deletion of sequences between -1288 and -1095 reduced transcriptional activity to approximately $30 \%$. These deleted sequences contain a characteristic CT-rich region (-1248 to -1191), followed by an Alu family sequence (-1190 to -934). Thus, these results are consistent with the hypothesis that Alu repeat sequences in the $5^{\prime}$-flanking regions have regulatory roles in NPPB expression [14]. Therefore, we assessed the association between mutations or polymorphisms in the $5^{\prime}$-flanking region of $N P P B$ and the presence of EH. In the present study, a novel VNTR was discovered, and a significant association between the VNTR and EH was found in female patients. The present study found that the number of patients with a 16 repeat allele of VNTR was lower in EH women than in NT women. It is well known that the plasma BNP level is higher in $\mathrm{EH}$ patients than in NT subjects, since an elevated blood pressure results in a high plasma BNP level, which is one of the protective factors for hypertension [4]. We compared the plasma BNP levels of patients with and without the 16 repeat allele and found that there was no significant difference between the two groups. In fact, there were not enough subjects to allow the association studies to be done by gender. Given our results, these limitations should be addressed in future studies. It is possible that factors other than the NPPB gene may have affected the BNP levels, since many factors, including cardiac function and blood pressure, are known to affect human plasma BNP levels. Thus, it is possible that the plasma BNP level is not an accurate reflection of the function of the NPPB gene.

In the present study, the overall distribution of the VNTR genotype and the allele frequency were significantly different in females but not in males. Gender-specific susceptibility to $\mathrm{EH}$ is an interesting finding, but its importance is still unclear [11]. Redfield et al. reported that BNP levels increased with age, and were higher in females than males among subjects with no known cardiovascular or detectable structural heart disease [18]. Maffei et al. reported that hormone replacement therapy increased BNP levels in postmenopausal women [19]. Although the absolute BNP value was different between these two studies, which used two different assays, the associations of the BNP levels with age and gender were consistent. Furthermore, the BNP level that had the optimal sensitivity and specificity for detecting systolic dysfunction in the overall population increased with age and was higher in women. This underscores the clinical relevance of the relationship of age, gender, and BNP. In both studies that used different assays, the effect of gender on BNP was substantial and independent of other factors [18]. Unfortunately, we were not able to obtain samples to measure plasma BNP and ANP levels, due to the difficulty in obtaining written informed consent for blood examinations from subjects not receiving medications.
In the Japanese population, it has been reported that plasma BNP levels are positively associated with age, urinary salt excretion, higher blood pressure, a high R-wave voltage in the 12-lead ECG (Code 3-1 or $3-3)$, and female gender $[20,21]$. On the other hand, Freitag et al., based on multivariate models adjusting for known risk factors, showed that elevated plasma BNP levels were associated with an increased risk of blood pressure progression in males but not in females. However, there was no significant trend of an increasing incidence of hypertension among BNP categories in either males or females. In a community-based sample, higher plasma BNP levels were found to be associated with an increased risk of BP progression in males, but not in females [22]. Further studies are needed to resolve these conflicting results.

Since there are many loci with a high degree of polymorphism in the number of tandemly repeated nucleotide sequence units, VNTR polymorphisms, also called minisatellites, were originally studied for linkage-mapping purposes. VNTRs have a highly polymorphic nature that makes them very useful as markers, both in linkage studies to map disease loci in families and in forensic applications. Recent reports indicate that some VNTR sequences may function as transcriptional or translational regulators, and that they may modify the function of a protein when the tandemly repeated region lies within the coding region of the gene [23]. Although no clear effect on transcription has been shown, it has been reported that a VNTR in the second intron of the serotonin transporter gene is associated with susceptibility to major depression [24].

We previously determined the structural organization of human natriuretic peptide receptor genes [25-28] and identified an insertion/deletion mutation in the 5'-untranslated region of NPRA [12]. The deletion encompasses eight nucleotides and alters the binding sites for the AP2 and zeste transcription factors. Transcriptional activity of the deletion allele was less than $30 \%$ that of the wild-type allele. The deletion allele was significantly more common in the EH group than in the NT group. These findings suggest that in Japanese individuals, this deletion in the NPRA gene reduces receptor activity and may confer increased susceptibility for the individual to develop EH or left ventricular hypertrophy $(\mathrm{LVH})$. Animal models with a deletion of this gene develop disorders that resemble the symptoms of subjects with a deleted allele in the 5 -untranslated region of NPRA. We previously isolated a missense mutation of the NPRA gene [29] and a VNTR polymorphism upstream of the NPRC gene; this VNTR influences blood pressure levels in obesity-associated hypertension [30]. Since the sampling of the above reports was different from the present experiment, it was impossible to analyze the relationship between systemic natriuretic peptide genes and EH.

Wang et al. reported that obese individuals have low circulating natriuretic peptide levels, which may contribute to their susceptibility to hypertension and 
hypertension-related disorders. The mechanisms linking obesity to hypertension have not been established, but sodium retention and excessive sympathetic tone are key contributors. Natriuretic peptides are important regulators of sodium homeostasis and neurohormonal activation; this raises the possibility that obese individuals have an impaired natriuretic peptide response [31]. Therefore, we examined the relationship between the genotype and BMI and found no significant association.

In conclusion, a novel VNTR in the $5^{\prime}$-flanking region of the $N P P B$ gene was discovered. This polymorphism was associated with $\mathrm{EH}$ in female subjects. However, this finding does not necessarily imply that there is a relationship between the NPPB gene and $\mathrm{EH}$. Further studies of other polymorphisms are needed to determine whether there is an association between the $N P P B$ gene and $\mathrm{EH}$.

\section{Acknowledgments}

We would like to thank Dr. Y. Watanabe and Dr. Y. Izumi for collecting the samples, and Ms. H. Tobe, M. Nakamura, and K. Sugama for their technical assistance. This work was supported financially by a grant from the Ministry of Education, Science and Culture of Japan (High-Tech Research Center, Nihon University).

\section{Conflict of interest}

The authors have declared that no conflict of interest exists.

\section{References}

1. Kangawa K, Matsuo H. Purification and complete amino acid sequence of alpha-human atrial natriuretic polypeptide (alpha-hANP). Biochem Biophys Res Commun. 1984; 118: 131-9.

2. Sudoh T, Kangawa K, Minamino N, Matsuo H. A new natriuretic peptide in porcine brain. Nature. 1988; 332: 78-81.

3. Sudoh T, Minamino N, Kangawa K, Matsuo H. C-type natriuretic peptide $(\mathrm{CNP})$ : a new member of natriuretic peptide family identified in porcine brain. Biochem Biophys Res Commun. 1990; 168: 863-70.

4. Nakao K, Ogawa Y, Suga S, Imura H. Molecular biology and biochemistry of the natriuretic peptide system. I: Natriuretic peptides. J Hypertens. 1992; 10: 907-12

5. Suga S, Nakao K, Itoh H, et al. Endothelial production of C-type natriuretic peptide and its marked augmentation by transforming growth factor-beta. Possible existence of "vascular natriuretic peptide system". J Clin Invest. 1992; 90: 1145-9.

6. Tamura N, Ogawa Y, Chusho H, et al. Cardiac fibrosis in mice lacking brain natriuretic peptide. Proc Natl Acad Sci USA. 2000; 97: 4239-44.

7. Mukoyama M, Nakao K, Saito Y, et al. Human brain natriuretic peptide, a novel cardiac hormone. Lancet. 1990; 335: 801-2.

8. Ogawa $\mathrm{Y}$, Itoh $\mathrm{H}$, Tamura $\mathrm{N}$, et al. Molecular cloning of the complementary DNA and gene that encode mouse brain natriuretic peptide and generation of transgenic mice that overexpress the brain natriuretic peptide gene. J Clin Invest. 1994; 93: 1911-21.

9. Jeunemaitre X, Soubrier F, Kotelevtsev YV, et al. Molecular basis of human hypertension: role of angiotensinogen. Cell. 1992; 71: $169-80$.

10. Nakayama T, Soma $M$, Sato $N$, et al. An association study in essential hypertension using functional polymorphisms in lymphotoxin- $\alpha$ gene. Am J Hypertens. 2004; 17: 1045-9.
11. Sano M, Kuroi N, Nakayama T, et al. The association study of calcitonin-receptor-like receptor gene in essential hypertension. Am J Hypertens. 2005; 18: 403-8.

12. Nakayama T, Soma M, Takahashi $Y$, et al. Functional deletion mutation of the 5 -flanking region of type A human natriuretic peptide receptor gene and its association with essential hypertension and left ventricular hypertrophy in the Japanese. Circ Res. 2000; 86: 841-5.

13. Nakayama T, Soma M, Rahmutula D, Ozawa Y, Kanmatsuse K. Isolation of the 5 '-flanking region of genes by thermal asymmetric interlaced polymerase chain reaction. Med Sci Monit. 2001; 7: 345-9.

14. Ogawa $\mathrm{Y}$, Itoh $\mathrm{H}, \mathrm{Nakagawa} \mathrm{O}$, et al. Characterization of the 5 -flanking region and chromosomal assignment of the human brain natriuretic peptide gene. J Mol Med. 1995; 73: 457-63.

15. Nakayama T, Soma M, Rehemudula D, et al. Association of $5^{\prime}$ upstream promoter region of prostacyclin synthase gene variant with cerebral infarction. Am J Hypertens. 2000; 13: 1263-7.

16. Morita A, Nakayama T, Soma M. Association study between $C$ reactive protein $(\mathrm{CRP})$ genes and ischemic stroke in Japanese subjects. Am J Hypertens. 2006; 19: 593-600.

17. Morita A, Nakayama T, Soma M, Mizutani T. The association between the calcitonin-related peptide a (CALCA) gene and essential hypertension in Japanese subjects. Am J Hypertens. 2006. in press

18. Redfield MM, Rodeheffer RJ, Jacobsen SJ, et al. Plasma brain natriuretic peptide concentration: impact of age and gender. J Am Coll Cardiol. 2002; 40: 976-82.

19. Maffei S, Del Ry S, Prontera C, Clerico A. Increase in circulating levels of cardiac natriuretic peptides after hormone replacement therapy in postmenopausal women. Clin Sci (Lond). 2001; 101: 447-53.

20. Kanda H, Kita Y, Okamura T, et al. What factors are associated with high plasma B-type natriuretic peptide levels in a general Japanese population? J Hum Hypertens. 2005; 19: 165-72.

21. Eguchi K, Kario K, Hoshide S, et al. Greater change of orthostatic blood pressure is related to silent cerebral infarct and cardiac overload in hypertensive subjects. Hypertens Res. 2004; 27: 235-41.

22. Freitag MH, Larson MG, Levy D, et al. Plasma brain natriuretic peptide levels and blood pressure tracking in the Framingham Heart Study. Hypertension. 2003; 41: 978-83.

23. Nakamura Y, Koyama K, Matsushima M. VNTR (variable number of tandem repeat) sequences as transcriptional, translational, or functional regulators. J Hum Genet. 1998; 43: 149-52.

24. Ogilvie AD, Battersby S, Bubb VJ, et al. Polymorphism in serotonin transporter gene associated with susceptibility to major depression. Lancet. 1996; 347: 731-3.

25. Nakayama T, Soma M, Takahashi $Y$, et al. Nucleotide sequence of the 5'-flanking region of the type A human natriuretic peptide receptor gene and association analysis using a novel microsatellite in essential hypertension. Am J Hypertens. 1999; 12: 1144-8.

26. Takahashi Y, Nakayama T, Soma M, Izumi Y, Kanmatsuse K. Organization of the human natriuretic peptide receptor A gene. Biochem Biophys Res Commun. 1998; 246: 736-9.

27. Rehemudula D, Nakayama T, Soma $M$, et al. Structure of the type $\mathrm{B}$ human natriuretic peptide receptor gene and association of a novel microsatellite polymorphism with essential hypertension. Circ Res. 1999; 84: 605-10.

28. Rahmutula D, Nakayama T, Soma M, et al. Structure and polymorphisms of the human natriuretic peptide receptor $C$ gene. Endocrine. 2002; 17: 85-90.

29. Nakayama T, Soma M, Mizutani $Y$, et al. A novel missense mutation of exon 3 in the type A human natriuretic peptide receptor gene: possible association with essential hypertension. Hypertens Res. 2002; 25: 395-401.

30. Aoi N, Soma M, Nakayama T, et al. Variable number of tandem 
repeat of the 5'-flanking region of type-C human natriuretic peptide receptor gene influences blood pressure levels in obesity-associated hypertension. Hypertens Res. 2004; 27: 711-6.

31. Wang TJ, Larson MG, Levy D, et al. Impact of obesity on plasma natriuretic peptide levels. Circulation. 2004; 109: 594-600. 